\title{
Influence of feed additive on the biological value of broiler chickens' white meat protein in technological stress conditions
}

\author{
A.V. Miftakhutdinov, E.R. Saifulmulyukov", and E.A. Nogovitsina \\ Federal State Budgetary Educational Institution of Higher Education "South Ural State Agrarian \\ University" Troitsk, Russia
}

\begin{abstract}
The aim of the research was to study the effect of feed additive on the biological value of broiler chickens' white meat protein under preslaughter stress conditions. The experiment was carried out on Arbor Acres broiler chickens in the conditions of an industrial poultry farm with floor housing technology. The main diet of poultry in the I experimental group was introduced with feed additive at a $1269 \mathrm{~g} / \mathrm{t}$ feed dose, II - at a dose of $1693 \mathrm{~g} / \mathrm{t}$. The control group poultry received only the main diet. As a result, the white meat of broiler chickens of experimental groups contained $1.5-6.8 \%$ more essential amino acids, substituted by $1.3-5.5 \%$ compared to control. In the amino acid composition of the broiler chickens' meat of the experimental group I, the most pronounced changes in the content of essential and dispensable amino acids were revealed; their level was above the control by an average of 3.7 and $2.9 \%$ respectively. White meat proteins of broiler chickens of the I experimental group were more biologically valuable; their amino acid score was above control by an average of $4.5 \%$.
\end{abstract}

\section{Introduction}

The productivity of broiler chickens is directly related to the production intensification and, accordingly, industrial stresses. Stress factors affect the nervous and endocrine systems and metabolic processes occurring in the poultry body, while reducing production rates of operation and overall efficiency of broiler poultry farming.

Many scientists agree that technological stresses in industrial poultry farming cause a decrease in weight increment, poultry safety, meat productivity and, as a result, the quality of meat. And the greatest productivity loss is noted precisely during the pre-slaughter period.

Mortality rates during the pre-slaughter period depend on many factors: poultry immunity, catching method, placement density, ambient temperature, conditions and duration of transport, distance to the slaughter point and conditions of preslaughter care [1, $2,3,4]$. The most frequent causes of broilers' death during the pre-slaughter period is the so-called "sudden death syndrome" and injuries, including fractures and liver ruptures [5].

${ }^{*}$ Corresponding author: ernest_saif@mail.ru 
The catch stage leads to a significant increase in production losses: poultry gets injured, thereby increasing the level of carcasses defect and mortality increase [6]. It is noted that the longer the poultry remains in the catcher's hands, the more chances of various kinds of injuries and subsequent carcasses defects $[7,8]$.

High ambient temperature during transportation is also a strong poultry stressor [9]. Higher transportation duration increases the risk of poultry feathering contamination with waste products, which leads to a decrease in the sanitary state of carcasses [10].

Prior to slaughter, 3 hours of stress leads to changes in the chemical composition and $\mathrm{pH}$ of poultry meat, manifestation of PSE signs [11]. At the same time, the main problem is associated with the decrease in the sensor characteristics of meat, which lead to an increase in technological losses when processing for meat products [12]. Stress affects the metabolism of amino acids, usually reducing their digestibility from feed [13].

The effectiveness of the stress protectors' use in pre-slaughter period for increasing the safety and meat productivity of poultry $[14,15,16]$ was proved.

In view of the above, the aim of the research was to study the impact of feed additive on the biological value of broiler chickens' white meat protein under pre-slaughter stress conditions.

\section{Materials and methods}

The experiment on "Pik-Antistress" feed additive application was carried out on broiler chickens of final cross hybrid Arbor Acres in the conditions of industrial poultry farm with floor management technology. The poultry was divided into three groups of 6,000 chicks each and kept in one room in separate sections. The scheme of feed additive application is presented in Table 1.

Table 1. Scheme of feed additive application

\begin{tabular}{|c|c|c|}
\hline Control group & Experimental group I & Experimental group II \\
\hline Basic diet (BD) & $\begin{array}{c}\text { BD+PIK-AS (1269 } \mathrm{g} / \mathrm{t} \text { feed for } \\
\text { 5 days before slaughter) }\end{array}$ & $\begin{array}{c}\text { BD+PICK-AS (1693 } \mathrm{g} / \mathrm{t} \text { feed } \\
\text { for 5 days before slaughter) }\end{array}$ \\
\hline \multicolumn{3}{|c|}{ Slaughter at 38 days } \\
\hline
\end{tabular}

The amino acid composition of white meat was determined via capillary electrophoresis method in the laboratory of the innovative research center of FSBEI HE South Ural State University. Statistical data processing was performed in the STATISTICA 12 program.

\section{Results and discussion}

The analysis of the amino acid content in poultry white meat protein gives a detailed assessment of the change in its biological value under pre-slaughter stress conditions (Fig. $1-3)$. 


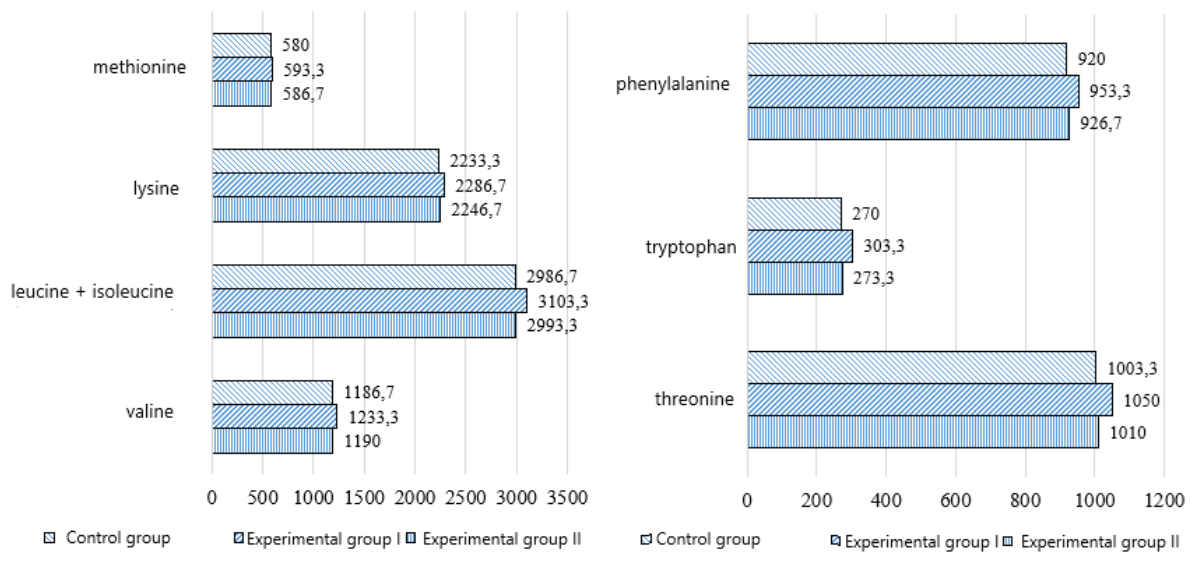

Fig. 1. The content of essential amino acids in white meat protein of broiler chickens, $\mathrm{mg} / 100 \mathrm{~g}(\mathrm{n}=9)$

Estimating the content of essential amino acids in the broiler chickens' white meat of experimental groups, we noted that the level of lysine and methionine was on average higher by $1.5-1.7 \%$; valine, leucine, isoleucine and phenylalanine - by $2.1-2.2 \%$, threonine by $2.7 \%$. The pronounced changes were in the tryptophan content; on average, its level was higher than the control group by experimental ones by $6.8 \%$.
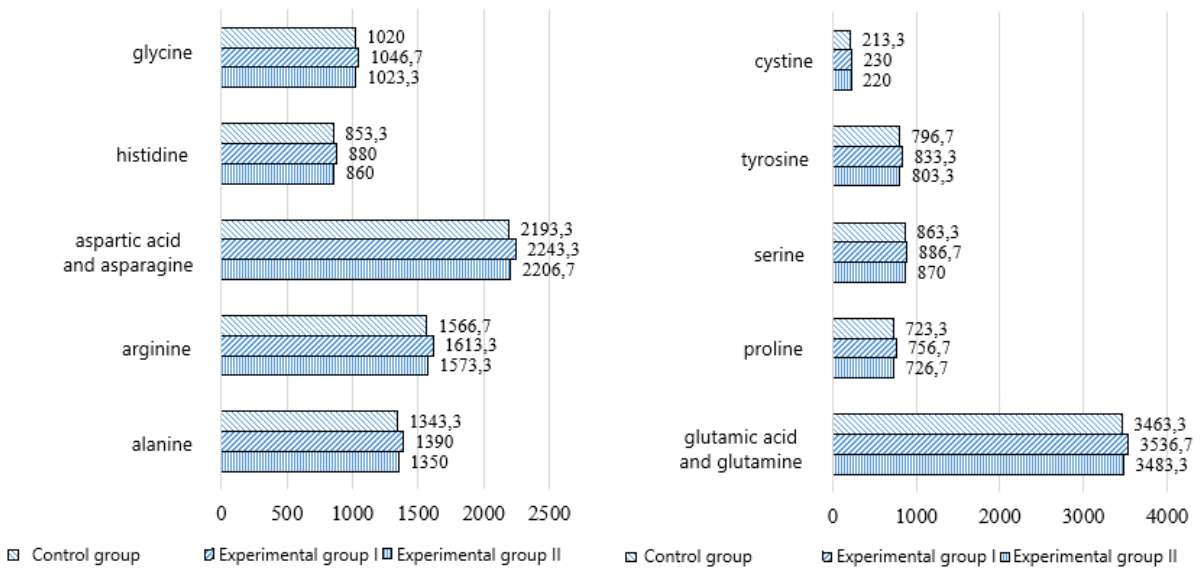

Fig. 2. Content of dispensable amino acids in broiler chickens' white meat protein, $\mathrm{mg} / 100 \mathrm{~g}(\mathrm{n}=9)$

As for the content of dispensable amino acids in the experimental groups, on average in relation to control, an increased content of glutamic, aspartic acids, glycine and serine by $1.3-1,7 \%$, arginine, histidine and alanine by $1.7-2.0 \%$, tyrosine and proline by $2.5-2.7 \%$, cystine by $5.5 \%$ was noted. 


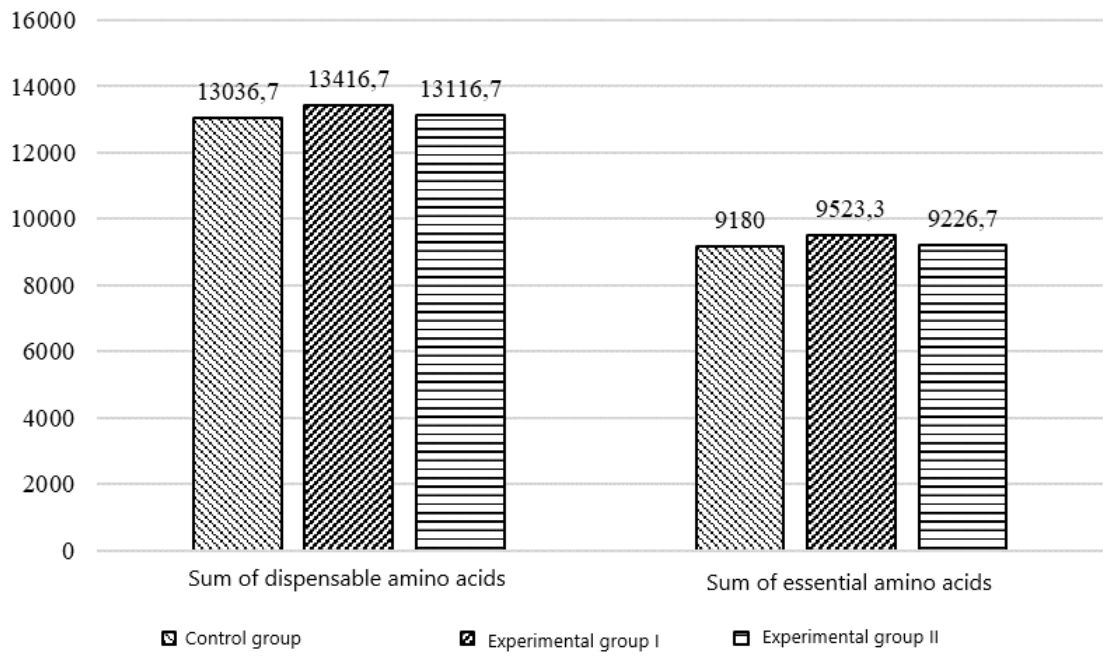

Fig. 3. The sum of essential and dispensable amino acids in the broiler chickens' white meat protein, $\mathrm{mg} / 100 \mathrm{~g}(\mathrm{n}=9)$

In terms of the sum of essential amino acids, the control group in general was on average inferior to experimental ones by $2.1 \%$, in terms of dispensable amino acids - by $1.8 \%$.

The most pronounced changes in the amino acid composition of meat were identified in the I experimental group, where the content of essential amino acids on average was higher by $3.7 \%$, dispensable $-2.9 \%$, in relation to control. The content of essential amino acids in the II experimental group was on average higher by $0.5 \%$, compared to control. The dispensable amino acid content was above control at between $0.3-0.8 \%$, except for cystine, the level of which was $3.1 \%$ higher.

The protein's amino acid score reflects the approximation of poultry meat's biological value to the reference sample (see table 2).

Table 2. Amino acid score of broiler chickens' white meat protein, \%

\begin{tabular}{|l|c|c|c|}
\hline \multirow{2}{*}{\multicolumn{1}{c|}{ Indicator }} & \multicolumn{3}{c|}{ Group } \\
\cline { 2 - 4 } & control & experimental I & experimental II \\
\hline Leucine + Isoleucine & 121.5 & 124.8 & 121.6 \\
\hline Lysine & 181.7 & 183.9 & 182.6 \\
\hline Methionine + cystine & 101.5 & 104.0 & 103.0 \\
\hline Phenylalanine + Tyrosine & 128.1 & 131.7 & 128.9 \\
\hline Threonine & 112.3 & 116.1 & 112.8 \\
\hline Tryptophan & 120.8 & 134.1 & 122.1 \\
\hline Valin & 106.2 & 109.1 & 106.4 \\
\hline
\end{tabular}

Amino-acid score of broiler chickens' white meat protein in experimental groups was higher by $1.5 \%$ for lysine and valine, leucine, and isoleucine - 1.7 , methionine and cystine 2.1 , phenylalanine and tyrosine $-2,2$, threonine -2.2 and tryptophane by $7.3 \%$, relative to control.

Despite the trend of increasing amino acid content in the broiler chickens' meat of both experimental groups, the white meat proteins of the I experimental poultry group were 
more valuable.

The established differences are consistent with the results of studies obtained by other authors, who noted the positive effect of similar feed additives on the poultry meat amino acid composition.

When using the preparation of succinic acid on broiler chickens, an increase in the essential amino acids content in the muscular tissue proteins of experimental groups' chicks in relation to control indicators was observed [17]. Supplements of betaine in the broiler chickens' diet affected the increase in the essential amino acids content in meat [18]. Carnitine introduction to the diet protects branched chain amino acid against oxidation in tissues [19].

Thus, for industrial poultry farming, the pre-slaughter period involves many stress factors, in response to which the poultry organism actively consumes the energy produced by using endogenous nutrients. Due to metabolic disorders, the biological value of meat decreases. The use of feed additives allows to save energy and plastic body resources.

\section{Conclusions}

1. In white meat of experimental groups' broiler chickens, the content of essential amino acids was higher on average by $1.5-6.8 \%$; dispensable - by $1.3-5.5 \%$, compared to control. 2 . In the amino acid composition of the broiler chickens' meat of the experimental group I, the most pronounced changes in the content of essential and dispensable amino acids were revealed; their level was above the control by an average of 3.7 and $2.9 \%$ respectively.

3. Amino-acid score of white meat proteins of experimental groups' broiler chickens was above the control for lysine and valine by $1.5 \%$, leucine and isoleucine - by $1.7 \%$, methionine and cystine -2.1 , threonine, phenylalanine, and tyrosine -2.2 and tryptophane $-7.3 \%$. White meat proteins of broiler chickens of the I experimental group were more biologically valuable; their amino acid score was above control by an average of $4.5 \%$.

\section{References}

1. C. Grilli, A. R. Loschi, S. Rea, R. Stocchi, L. Leoni, F. Conti British Poultry Science, 56(1), 1 (2015)

2. F.M.C. Vieira, M. Deniz, I.J.O. da Silva, J.A.D. Barbosa, A.M.C. Vieira, F.S. Goncalves Semina-Ciencias Agrarias, 36(6), 3887 (2015)

3. L. Jacobs, E. Delezie, L. Duchateau, K. Goethals, F. A. M. Tuyttens, Poultry Science. 96(2), 266 (2017)

4. G. Di Martino, K. Capello, E. Russo, M. Mazzucato, P. Mulatti, N. Ferre, A. Garbo, M. Brichese, S. Marangon, L. Bonfanti, Animal, 11(12), 2295 (2017)

5. K.E. Kittelsen, E.G. Granquist, O. Kolbjornsen, O. Nafstad, R.O. Moe, Poultry Science, 94(11), 2622 (2015)

6. M.L. d. V. Queiroz, J.A.D. Barbosa Filho, L.M. Duarte, D. d. Brasil, C.R.F. Gadelha, Brazilian Journal of Poultry Science, 17(1), 37 (2015)

7. N. Langkabel, M.P.O. Baumann, A. Feiler, A. Sanguankiat, R. Fries, Poultry Science, 94(8), 1735 (2015)

8. K. E. Kittelsen, E. G. Granquist, G. Vasdal, E. Tolo, R. O. Moe, Animal Welfare, 24(4), 387 (2015)

9. R.S. Spurio, A.L. Soares, R.H. Carvalho, V. Silveira, M. Grespan, A. Oba, M. Shimokomaki, Animal Science Journal, 87(2), 277 (2016) 
10. L. Jacobs, E. Delezie, L. Duchateau, K. Goethals, F. A. M. Tuyttens, Poultry Science, 96(2), 259 (2017)

11. R.T.V. Fernandes, A.M.V. de Arruda, A.D. Melo, J.B.M. Marinho, R.T.V. Fernandes, L.C. de Figueiredo, Journal of Animal Behaviour and Biometeorology, 4(4), 93 (2016)

12. P. M. Groff-Urayama, J. B. Padilha, J. Pia, S. E. Takahashi, Veterinary and Zootechnics, 12(2), 33 (2018)

13. Walid Habashy, M. Milfort, Kwaku Adomako, Youssef Attia, Romdhane Rekaya, Samuel Aggrey, Poultry Science, 96 (2017)

14. V.I. Fisinin, A.V. Miftakhutdinov, D.E. Anosov, Russian Agricultural Sciences, 42(1), 97 (2016)

15. A.V. Miftakhutdinov, E.R. Saifulmulyukov, E.A. Nogovitsina, E.A. Miftakhutdinova, IOP Conference Series: Earth and Environmental Science, AgroCON-2019, 012050 (2019)

16. N.A. Zhuravel, A.V. Miftakhutdinov, S.F. Suchanova, IOP Conference Series: Earth and Environmental Science. AgroCON-2019, 012056 (2019)

17. T. Kurmakaeva, Y. V. Petrova, A. Avdeyenko, Herald of the NI Vavilov Saratov State Agrarian Univ, 25 (2013)

18. M. Nutautaitė, S. Alijošius, S. Bliznikas, V. Šašytè, V. Vilienè, A. Pockevičius, A. Racevičiūtè-Stupelienè, Italian Journal of Animal Science, 19(1), 621 (2020)

19. Shahram G. Adabi, Ross Cooper, Necmettin Ceylan, Muzaffer Corduk, World's Poultry Science Journal, 67, 277 (2011) 